\title{
Urban Structure as a Precondition of Regional Development. Evidence from Slovakia
}

\author{
Martin MARIS ${ }^{*}$, Marian KOVACIK² \\ * Corresponding author \\ ${ }^{1}$ Slovak University of Agriculture, Department of Regional and Rural Development, Nitra, SLOVAKIA \\ ${ }^{2}$ Slovak University of Agriculture, Department of European Policies, Nitra, SLOVAKIA \\ $\triangle$ martin.maris@uniag.sk (D) https://orcid.org/oooo-0oo1-8276-3308 \\ $\triangle$ marian.kovacik@uniag.sk (iD https://orcid.org/oooo-0oo2-9164-3719 \\ DOI: 10.24193/JSSPSI.04.CSPTER \\ https://doi.org/10.24193/JSSPSI.04.CSPTER
}

K e y w o r d s: urban patterns, monocentricity, polycentricity, coefficient of concordance, economic development

\begin{abstract}
A B S T RA C T
The main objective of the paper was to investigate a possible link between the urban structure and regional economic performance in Slovakia, at district level (LAU1). Based on the selected urban indicators, we identified distinct patterns in terms of urban structure and economic performance in Slovakia through the Agglomerative Hierarchical Clustering (AHC) method. The "inner" urban pattern includes districts located predominantly in the central part of the country with some extension to the west and east. Common characteristics of this pattern are higher centrality, clustering, and monocentric urban cores. The "outer" urban pattern includes districts located predominantly at the periphery, along the borders. The common characteristics of this pattern are the dispersed urban patterns and polycentric settlement structures. The underlying urban structure was matched with the economic conditions prevailing in each district for evaluating the degree of concordance. The kappa coefficient of concordance has shown a scant relation between the urban structure and economic performance of regions at the district level (LAU1). According to the main findings, underlying urban pattern (clustered or dispersed one) in any particular district does not preclude economic success or failure of its regional economy.
\end{abstract}

\section{INTRODUCTION}

The main objective of the paper is to investigate a possible link between the urban structure and regional development in the local administrative units in Slovakia (LAU1 level). The objects of our study are the Slovak settlements, consisting of units, contained in districts (LAU1). The thematic aspect of the study also includes the analysis of urban patterns prevailing on regional level (NUTS 3). Hence, specific concepts of settlement morphology are evaluated: centrality, concentration, polycentricity, and city size. Secondly, the link between different urban patterns and development is evaluated. Recent discussions in regional studies and in economic development have returned to the centrality of cities, innovation, technology diffusion, and to overall economic growth. Conventional wisdom suggests that the three C's of compact, concentrated and connected cities are key to driving competitiveness and fostering innovation (Clark et al., 2018). Cities are essentially focal points in an economy where people come together primarily to exchange goods, to trade. The forces that create such clusters are usually defined to be those leading to agglomeration economies whereby industries and services prosper if they are close to each other and close to their market (Batty et al., 2003). Still, there is relatively little evidence on the relation between 
polycentricity and growth. So far, research into the benefits of polycentric strategies has provided inconclusive evidence (Alonso, 1970; Liu and Liu, 2018). This study aims to provide some further insights into this topic on the example of Slovakia. The aim of the paper is to clarify the links, if any, between the economic development and monocentric or polycentric urban structure at the local level (LAU1) in Slovakia. Lityński et al. (2021) state that, while growing urbanization does not negatively impact the national economy or national finances, it affects the regional economy and its growth. Furthermore, their research proved that compact local economies are important for increasing regional economies. They concluded that national spatial strategies should focus on stimulating the suburbanization process. Since 1990, a decrease in average urban population density has occurred in more than half of the OCED countries. In Slovakia, as well as Germany, a substantial decrease in urban population and settlements fragmentation occurred after 2000, while the most significant increase of urban centres was also recorded, the same being observed in Denmark and Slovenia (OECD, 2018).

The above mentioned long-term processes might be explained by the acting of centripetal and centrifugal forces, which contribute to the changing rural-urban fabrics. The concept of involving centripetal and centrifugal forces was applied broadly to the geographical sciences by Colby (1933); and, for decades, these terms have been key elements used in explaining the development of cities and regions (Krzysztofik, 2016). However, Krugman (1996) links this topic with uneven regional development, which clearly involves a tension between the "centripetal" forces that tend to disrupt such agglomerations. Among centripetal forces, there is a basic distinction between the natural factors that favour a site - such as a good harbour or a central position and the external economies that are acquired and the self-reinforcing advantages of a site.

On the side of centrifugal forces, there is a similar distinction between nonmarket diseconomies and factors such as land prices, which are fully mediated by the market. The centralizing (centripetal) forces cause cities to form, in the first place, and to agglomerate into fewer and larger cities over time. The decentralizing (centrifugal) forces tend to limit the growth of city size and alsoto create more but smaller cities dispersed throughout the territory (Geltner et al., 2014).

External economies exist when the scale of urban environment adds to productivity. There are at least three dimensions over which these externalities may extend. These are the industrial, geographic and temporal scope of economic agglomeration economies (Rosenthal and Strange, 2004). Recent efforts to measure the extent of urbanization economies have focused on estimates of the productivity gain accruing to activities that are located in larger urban areas. Earlier studies suggest six to eight percent of productivity gain for metropolitan areas when this population threshold is reached (Segal, 1976; Sveikauskas, 1975). In their review, Rosenthal and Strange (2004) learned that city size tends to increase individual productivity by 3 to $8 \%$. Melo et al. (2009) realized a meta-analysis of estimates of urban agglomeration economies. Although the productivity gains of urban agglomeration economies are generally found to be positive, there is a great deal of variability in the magnitude of reported estimates. The countryspecific effects, the industrial coverage, the specification of agglomeration economies, and accounting for both endogeneity of labour force quality and unobserved cross-sectional heterogeneity in time-variant labour quality can give rise to large differences in the results reported in the literature.

The decentralizing forces are holding back urban agglomeration and result in a larger number of smaller cities; they include factors that make it less efficient or more costly to produce goods and services in large cities. For instance, megacities often lead development in developing countries, while small- and medium-sized cities play more of a key role in many developed countries (Kourtit et al., 2015; Partridge, 2010). Satterthwaite and Tacoli (2003) suggest that small and intermediate urban centres are places where most rural people and rural enterprises interact. There are many activities that such centres play in supporting social and economic development within rural areas providing rural population with access to education and healthcare and providing a location for agricultural extension services, like irrigation offices, and agroindustries linked to local products. Tacoli $(1998,2003)$ and Akkoyunlu (2015) point to rural-urban linkages, which include the network flows between agriculture, manufacturing, and service sector. Also, many households in both urban and rural areas rely on the combination of agricultural and non-agricultural income sources for their livelihoods.

Small settlements play an important role in urban and regional development. Hamlets with less than 200 inhabitants can be found in the north-western part of Slovakia and settlements with less than 500 residents are typical for the northern part of the country. In general, settlement centres are localities with a higher number of residents. In Slovak conditions, these are represented by district towns with at least 10,000 inhabitants (Statistical Office of the Slovak Republic, 2021).

Urbanization, along with suburbanization and possibly re-urbanization, is a relatively well-known phenomenon, being investigated in several studies in the context of the Slovak Republic (Faltan and Pašiak, 2004; Hrdina, 2010; Zubrický, 2014; Šveda and Šuška, 2014). Hrdina (2010) states that, after 1990, the further 


\section{Urban Structure as a Precondition of Regional Development. Evidence from Slovakia Journal of Settlements and Spatial Planning, Special Issue, (2022) 25-35 Cities, Suburbs and Peripheries in Theory and Empirical Research}

growth of more populated settlements came to a halt. This development is reflected in the stagnation of larger cities and in the slight growth of rural communities, especially in the hinterland of these cities.

The change in socio-economic conditions has created the preconditions for natural suburban growth even in the hinterland of many cities (Šveda and Šuška, 2014). Hrdina (2010) further recalls that, in the context of housing relocations, the greatest growth is experienced by the most attractive municipalities in the hinterland, in terms of accessibility to the centre. He talks about the trend of suburbanization around the largest cities, while in urban agglomerations the socalled concentrated deconcentration is observed; this is described by the arrival of inhabitants from other territories to the hinterland of larger, locally and commercially attractive cities.

The relationship between settlement structure and regional development has become subject of research in previous studies (see also Sloboda, 2005; Tichý, 2005; and Žárskaet al., 2005). Overall, they emphasize the disadvantageous position of small municipalities (up to 1000 inhabitants), their high number, and uneven spatial distribution within the Slovak Republic, which implies further barriers to regional development. The Ministry of Transport and Construction of Slovakia (2019) emphasizes the implementation of the polycentric concept as a settlement system based on the so-called functional territorial units, e.g. urban functional areas and metropolitan growth areas. The application of this concept should lead to the creation of a balanced polycentric settlement system as one of the tools for eliminating interregional differences.

\section{THEORY AND METHODOLOGY}

Formally, we observe $m$ regions $(i=1,2, \ldots$, $m$ ), with $n_{i}$ settlement frequencies, $(i=1,2, \ldots, m)$ units. There is $m=79$ regions (LAU1 level districts), consisting of $n=2927$ (settlement) units. Primary, we analyze the urban structure of each district using the selected indicators. These indicators are employed to evaluate the spatial settlement structure, prevailing in each district. Urban spatial structure is conceptualized by two spatial dimensions: the degrees of centralization and concentration (Anas et al., 1998). This indicator measures how unevenly the population in the urban area is distributed. For this purpose, Theil's Entropy (Tsai, 2005; Limtanakool et al., 2007) would provide useful results. The entropy indicator ranges between 0 and 1 , with $\mathrm{o}$ indicating perfect concentration (Veneri, 2015). Formally, we might write:

$$
E N T R=\frac{\sum_{i=1}^{n} P D E N_{i} \times \log \left(\frac{1}{P D E N_{i}}\right)}{\log (N)}
$$

where:

$$
\operatorname{PDEN}_{i}=\frac{D E N_{1}}{\sum_{i=1}^{n} D E N_{i}}
$$

$n$ - number of local units (settlements).

Centrality is the degree to which residential or non-residential development (or both) is located to the Central Business District (CBD) of an urban area. The centralization index measures how quickly the cumulative proportion of urban population captures the mean distance of the population relative to the centre of interest by multiplying an area's distance from the centre by its share of population (Galster et al., 2001). Formally stated:

$$
\frac{1}{\sum_{j=1}^{n-1} \tilde{x}_{i} d_{j}}
$$

where:

$$
\begin{aligned}
& \tilde{x}_{i}-\text { population share in settlement unit } i \text {; } \\
& d_{j} \text { - distance from } j \text { to } i \text {. }
\end{aligned}
$$

For the purpose of our study, we measured the distance from the unit $j$ to the city $i$ straightforwardly, assuming a homogenous surface without obstacles. A higher value of the index suggests higher centralization, hence clustering the settlements around the central city, whilst a lower value suggests a more disperse settlement structure.

Centricity is the extent to which an urban area is characterized by a monocentric (as opposed to a polycentric) pattern of development. If CBD is the only locus of intense development, then the area has a monocentric structure, and its centricity is maximized. If the same activities are dispersed over several intensively developed places and each contains an agglomeration of activities that represent a substantial proportion of the total of such activities in the region, then it is polycentric (Galster et al., 2001). For our purpose, we outlined centricity based on population density. If population density, in the absolute value of the particular settlement, exceeds at least one standard deviation of an average population density of the whole district, we consider the settlement as nuclear; formally written:

$$
N_{i}=\left\{\begin{array}{l}
1^{i \geq 1 \sigma} \\
0_{\text {otherwise }}
\end{array}\right\}
$$

Both indexes (centrality and centricity) were used by Galster et al. (2001) in their study focusing on urban sprawl. We undertook and adjusted their measures for the purpose of our study. In the case of centrality measures, we used the area of the district at the LAU 1 level, whereas Galster et al. (2001) used the 
city's urban area as a measuring unit. In the case of centricity use, we simply measured the population density of settlements located in particular districts. If the population density of some particular settlement exceeded at least one standard deviation of an average population density in a given district, we would consider the settlement as another city core.

The last indicator used measures the mean size of the city population. It is the average size of the city in the region where the population resides.

$$
M C=\frac{\sum_{i=1}^{m} c_{i}^{2}}{P}
$$

where:

$c_{i}-$ population of the city $i$

$P$ - total population of the district;

$m$ - total number of settlements.

For evaluating urban structures in districts we used the method of agglomerative hierarchical clustering (AHC) applied to a set of examining objects districts, based on the examining indicators (concentration, centralization, nuclearity, mean size of the city). For intercepting the dissimilarity (or similarity) of objects we used the Euclidean distance the square root of the sum of square distances, formally written:

$$
V_{y z}=\sqrt{\sum_{i=1}^{k}\left(y_{i}-z_{i}\right)^{2}}
$$

where:

$$
\begin{aligned}
& \mathrm{y}, \mathrm{z} \text { - vectors (observations); } \\
& \mathrm{k} \text { - examined variable (Hendl, 2012). }
\end{aligned}
$$

The result of hierarchical clustering (dendrogram) is a way of arranging items in a hierarchy based on the distance or similarity between them. The result of clustering calculation is presented either as the distance or the similarity between the clustered items depending on the selected distance measure. Cluster analysis would help us find clusters of similar districts and thus revealing the common trends and patterns.

To link the common urban patterns with regional development, we used the AHC method once again on the same sample (districts), however observing different variables. In this case, the variables reflect the development level of the LAU 1 districts. As observation variables, we selected common social-economic indicators based on 5-year average (2016-2020): unemployment rate, average nominal wage, migration balance, nominal price of urban land (built-up area in $\mathrm{sq} \mathrm{m})$.

The final output is two different dendrograms (denoted D1 - urban dendrogram and D2 - economic dendrogram) consisting of district groups based on dissimilarity between the groups and similarity within the groups.

Of utmost importance is to find the 'degree of compliance' among the dendrograms built on two distinct sets of variables (urban vs. economic). Compliance means the same composition of districts within and between the groups across both dendrograms. As such, the null hypothesis is stated, that there is zero compliance across both dendrograms, formally expressed as 'kappa coefficient of concordance'

$$
\begin{aligned}
& \mathrm{H}_{\mathrm{o}}: \mathrm{k}=\mathrm{O} \\
& \text { and, as alternative hypothesis: } \\
& \mathrm{H}_{1}: \mathrm{k} \neq \mathrm{O}
\end{aligned}
$$

The $n_{i j}$ frequencies $(i=1,2, \ldots, K)$ denote the number of objects (districts) assigned to the i-category (D1) and j-category (D2). Summing up then ii frequencies along the diagonal, would get the number of concordances (number of concordant district pairs) among the categories across both dendrograms. Again, not the order of groups within dendrograms is important, but the degree of concordance within the groups in both dendrograms. Hence, the ideal state is the same composition of districts within the groups in both dendrograms. Dividing the sum of concordant district pairs with total number possible number of district pairs would get a probability estimation $\mathrm{p}_{\mathrm{o}}$ that both dendrograms will match together. Thus, the number $p_{e}$ estimates the random probability of concordance. Hence, the number of districts is $n=79$. The number of possible district pairs would get as a two-element combination of number 79 without repetition:

$$
C_{k}(n)=\frac{n !}{k !(n-k) !}
$$

The kappa coefficient of concordance is formally written as:

$$
k=\frac{p_{0}-p_{e}}{1-p_{e}}
$$

where:

$$
p_{e}=\frac{1}{n^{2}} \sum_{i=1}^{k} n_{i j}
$$

Coefficient kappa gets value 1 if there is total concordance between the search object pairs and value $\mathrm{o}$, if there is any concordance between the object pairs.

\section{RESULTS AND DISCUSSION}

The first part of the results reveals the features of urban structure studied at district level (LAU1) in Slovakia. Figure 1 shows the studied indicators 


\section{Urban Structure as a Precondition of Regional Development. Evidence from Slovakia \\ Journal of Settlements and Spatial Planning, Special Issue, (2022) 25-35 \\ Cities, Suburbs and Peripheries in Theory and Empirical Research}

cartographically (mean city size, polycentricity, Theil entropy, Galster index).

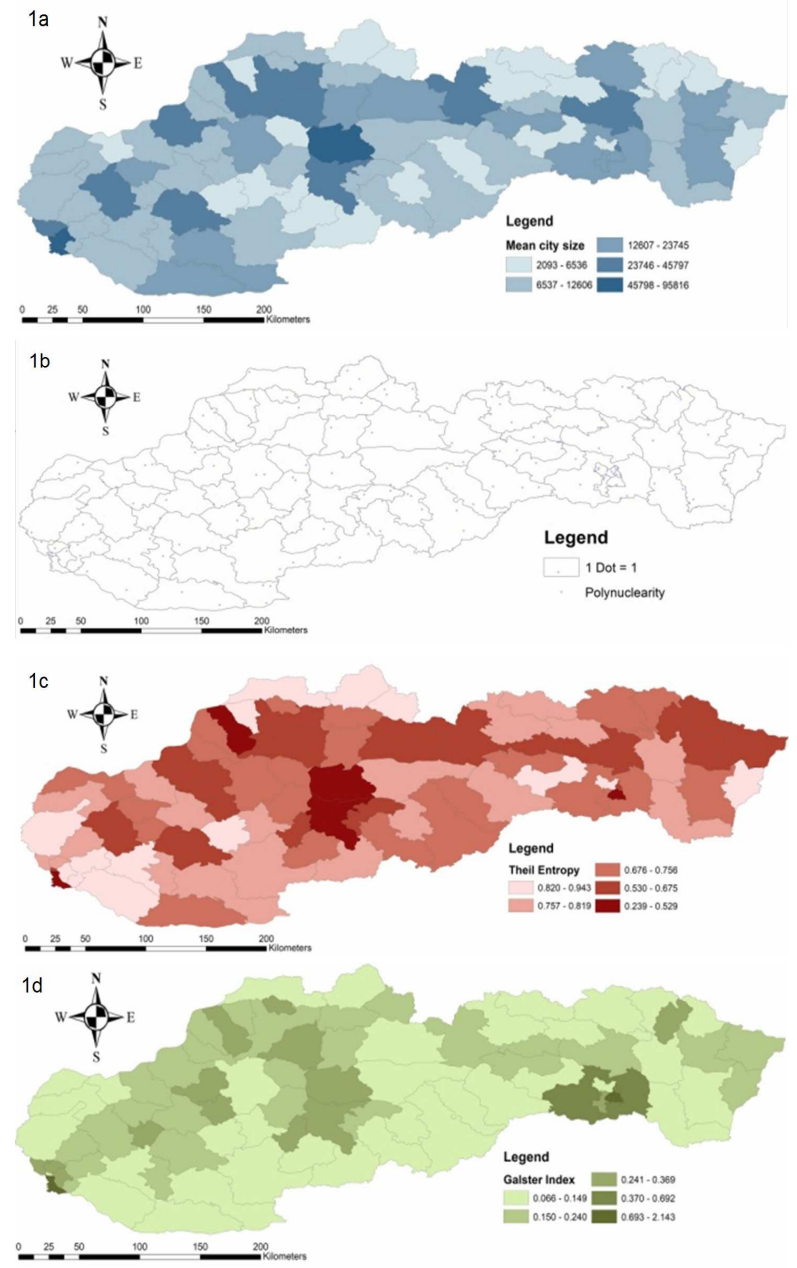

Fig. 1. Urban development indicators at the district level (LAU1) in Slovakia.

Figure 1a shows the mean city size expressed by the average number of inhabitants per one settlement in each district. We can observe a considerable variation in the mean size of settlements in districts in Slovakia. The most populous places are predominantly concentrated in the west (Bratislava urban agglomeration), east (Kosice metropolis), and north parts of the country (Zilina and Banska Bystrica regional capital city). Relatively low populous areas are scattered along the Slovak-Hungarian border in the south and the Slovak-Polish border in the north of the country.

Figure $1 \mathrm{~b}$ shows the degree of polycentricity in districts of Slovakia. In general, we observe a mixed pattern of districts with monocentric and polycentric settlement structures. The highest degree of polycentricity is visible in the eastern part (leftward) of the country, where multiple population cores are found in the same district. However, excluding the Kosice metropolis, most of these population nuclei just comprise the Roma minority, which lives in shanty towns and does not represent the real urban fabric. In the western part of the country, the highest polycentricity degree is shown by Bratislava urban agglomeration, representing a separate urban core.

Figure 1c represents the calculated Theil entropy as a proxy for measuring the level of clustering of settlements in each district. In our study, a major district city is represented by the settlement to which all other settlements (within the district) should gravitate. The Theil entropy index depends on the population of the gravitating settlement and the population base of the district city. A higher value of the index means a rather balanced distribution of population in the settlements at the district level. The overall picture of Slovakia is rather mixed, the lowest entropy values being registered by districts in the western part of the country, around Bratislava. These districts are currently attractive for housing and their settlements are experiencing population inflows. The rather balanced distribution also maintains several districts located in the southern and northern parts of the country. They are characterized by rather fragmented settlements structure with a higher share of small settlements, of up to 1,000 inhabitants. Nevertheless, a typical monocentric pattern prevails in the inner part of the country, in the middle and eastern areas.

Finally, the Galster index represents the degree of centrality at the district level. The index depends on the area of the district, on the population base of a major city, and on the distance and population of the gravitating settlements towards the major city. The greater size of the district city and shorter distance between the settlements and city within the same district means higher centrality and vice-versa. The overall pattern resembles the previous one, in which case mostly monocentric districts show a higher degree of centrality and vice versa. The inner part of Slovakia and also Bratislava urban agglomeration in the west, and Kosice metropolis in the east contributes to this pattern. However, the outer districts located along the Slovak borders mostly show a decentralizing pattern.

Figure 2 represents a socioeconomic overview of the Slovak districts. The variables expressed cartographically in the upper (average wage level in euro, migration in relative number of inhabitants) and lower right parts of the figure (land prices in euro and average rate of unemployment) contribute to a largely uniform pattern. Western Slovakia, led by the Bratislava region, and the relatively developed middle and northern parts of Slovakia belong to economically developed areas. On the other hand, the southern part, along the Hungarian border, and the eastern one, except for the Kosice metropolis, represent the least developed areas in the context of all analysed variables. This situation fits the lower left part of the figure representing the five-year average unemployment rate, which is found predominantly in the southern and eastern parts of the country. 


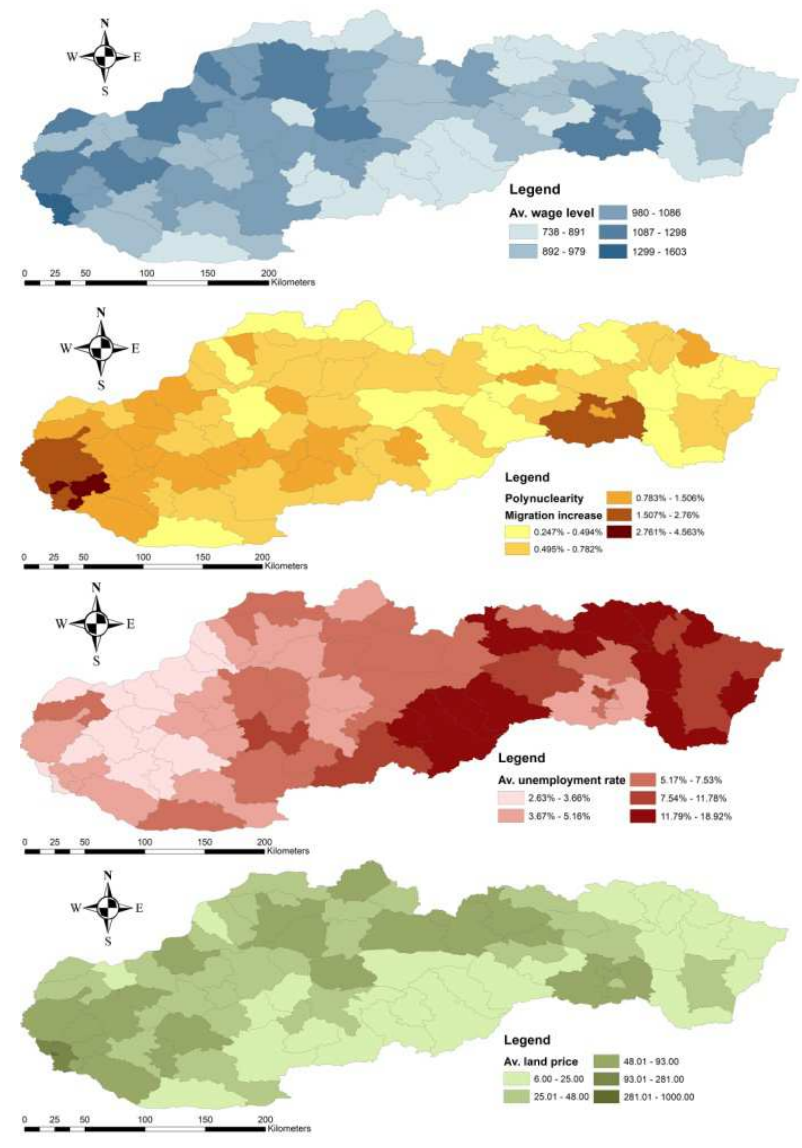

Fig. 2. Economic development indicators at the district level (LAU1) in Slovakia.

Figure 3 and Figure 4 show the results of Agglomerative Hierarchical Clustering dividing districts at the LAU1 level into subgroups according to the similarity criterion. There are two dendrograms based on urban indicators (Fig. 3) and on socioeconomic indicators (Fig. 4). The main method used for the clustering of similar districts is Ward's linkage, which minimizes the variance of the clusters being merged.

Figure 3 shows the assembly of districts based on computed urban indicators (mean city size, Theil entropy, Galster index and Polycentricity). We can observe at least three distinct clusters. The smallest one (C1) contains just two districts (Bratislava V and Kosice III), dissimilar from all the others. Next, cluster C2 (displayed in red) is more homogenous than cluster $\mathrm{C}_{3}$ (displayed in green) which consists of four distinct subsets. In the $\mathrm{C} 2$ cluster, we can observe three distinct subsets containing districts located predominantly in the western and eastern parts of Slovakia. The common main feature of these districts is the monocentric urban core, which dominates in the area and to which other smaller settlements gravitate. Furthermore, these districts are characterized by a higher level of centrality, higher level of clustering, and single nucleus; however, the size of the core city varies substantially.

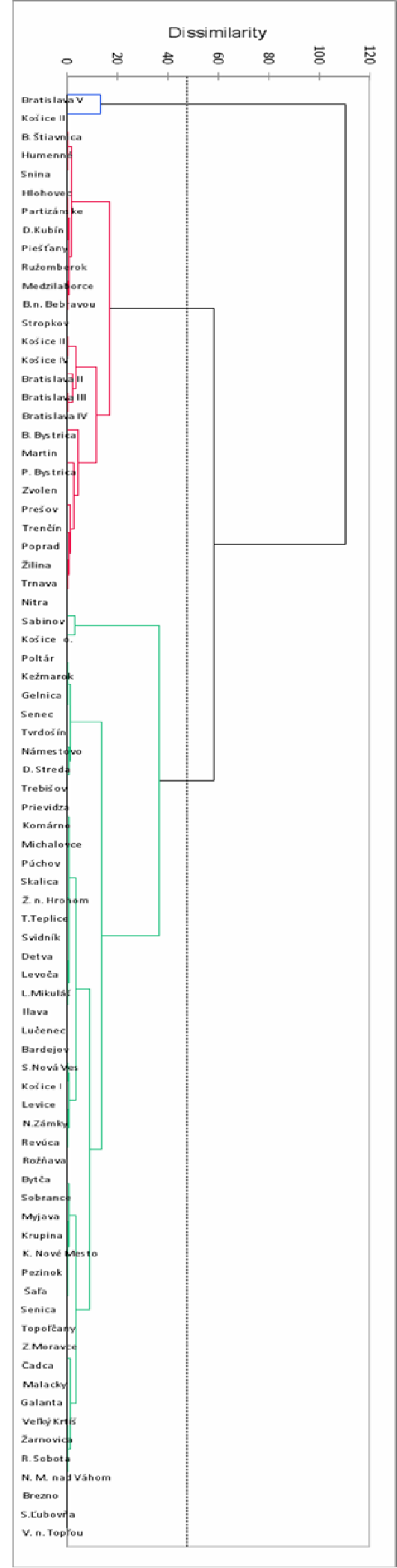

Fig. 3. Groups of clustered districts using the urban indicators, based on the Ward's linkage method, selfcomputation, XLStat. 


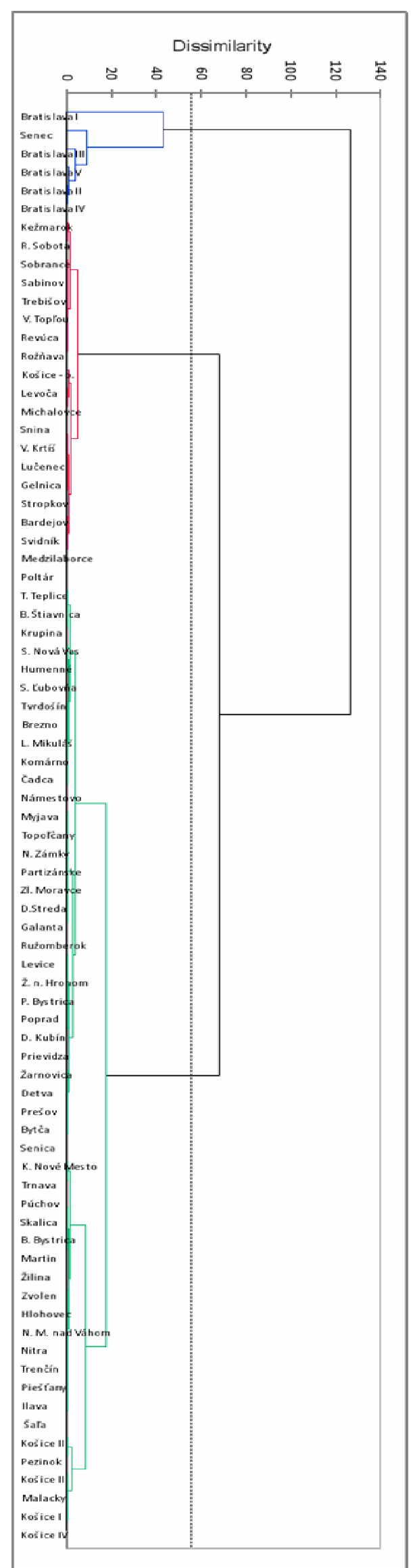

Fig. 4. Groups of clustered districts using the socialeconomic indicators, based on the Ward's linkage, selfcomputation, XLStat.
In the $\mathrm{C}_{3}$ cluster, we can observe districts located predominantly in the centre of Slovakia extending to the northern and southern areas of the country. The common features of these districts are the scattered settlements of various sizes, two or more urban cores, and overall decentralized urban patterns.

Figure 4 shows the assembly of districts based on computed socioeconomic indicators (unemployment rate, average wage, migration rate, and urban land prices). Overall, we note three distinct clusters. The smallest one (displayed in blue) includes Bratislava agglomeration and surrounding areas. The next one (displayed in red) contains two distinct subsets representing the most underdeveloped regions in Slovakia. The third cluster (displayed in green) consists of four distinct subsets of districts of various development levels. Bratislava agglomeration and the surrounding areas ( $\mathrm{C} 1$ cluster) represent the most developed part of Slovakia, with highest wage level, migration inflow, and land prices. Next, the C2 cluster (displayed in red) represents the most underdeveloped districts in Slovakia, predominantly located in the south and east of Slovakia. In general, they are impacted by various structural problems. Finally, the $\mathrm{C}_{3}$ cluster (displayed in green) includes multiple districts with varying levels of development. They are located in all parts of Slovakia, with various economic issues.

Finally, we were interested in finding some possible link between the underlying urban structure within the districts and their level of development. For this purpose, the measure of concordance was established. As a measure, we computed the kappa coefficient of concordance, $\kappa$. Firstly, for computing the kappa coefficient, we calculated the number of possible district pairs. We computed the possible number of district pairs as a two-element combination of number 79, without repetition:

$$
C_{2}(79)=\frac{79 !}{2 !(79-2) !}=3081
$$

This resulted in 3081 possible district pairs in total. Dividing the sum of concordant district pairs with total number possible number of district pairs got a probability estimation $\mathrm{p}_{\mathrm{o}}=0.278$. Next, the number $\mathrm{p}_{\mathrm{e}}$ estimates the random probability of concordance, set $\mathrm{p}_{\mathrm{e}}$ $=0.213$. Finally, the kappa coefficient of concordance was computed:

$$
k=\frac{0.287-0.213}{1-0.213}=0.0822
$$

This is an indeed very small value. So, we might say that the degree of concordance shows only a limited link between the urban pattern and the economic development at the district level (LAU1). 


\section{CONCLUSION}

The main objective of the paper was to analyse possible conditional relations between the predominant urban pattern and the development degree at the local level (LAU1) in Slovakia. The object of the research was the LAU 1 district sample. The subject of research was the urban pattern and the underlying economic conditions prevailing in each district. Regional urban patterns were analyzed based on a distinct set of indicators particularly describing the degree of centrality, centricity, clustering, and the mean city size of the district. On the other hand, the economic conditions in each district were analyzed by a set of indicators considering unemployment level, urban land prices, migration inflow, and average wage level.

Regarding the analyzed urban patterns, we might speak about emerging "inner" and "outer" patterns, which share different urban features. The "inner" urban pattern contains districts predominantly located in the central part of the country and clustering in the west (Bratislava urban agglomeration) and east (Kosice metropolis). They are characterized by a higher level of centrality, settlement clustering, and a dominating single urban core. On the other hand, the "outer" urban pattern contains districts predominantly located at the periphery of the country, mainly along the Hungarian, Polish and Ukrainian borders. Common features include higher settlement decentralization, two or more urban cores, and dispersed settlement structure. Some of these findings are in line with previous empirical results (JRC, 2020; Drinka and Majo, 2016; Havierniková et al., 2017; Maris et al., 2019). Particularly, Drinka and Majo (2016) point to apparent differences in 'large' municipalities distribution (municipalities up to 2000 inhabitants) over the country. Large municipalities are predominantly concentrated in the western part of Slovakia (Bratislava - 23.6\%, Trnava - 16.3\%, Nitra $12.1 \%$ and Trencin - 10.1\%), significantly dispersed in the central part and at least in the east of Slovakia. The eastern part of Slovakia comprises only $5.7 \%$ of the large municipalities; however, here is where most 'small' municipalities (up to 500 inhabitants) are predominantly concentrated. Moreover, these municipalities often face depopulation, which further contributes to disperse settlement structures. Regarding the long-term development processes, Maris (2020) found fast-growing municipalities predominantly located in the west, surrounding the Bratislava agglomeration, north and east, surrounding the Kosice metropolis. These clusters of municipalities tend to urbanize further, thereby agglomerating to more compact urban cores. On the contrary, fast-declining municipalities are located along the Hungarian, Polish and Ukrainian borders, whilst the prevailing unfavourable conditions further contribute to the 32 migration outflow and further atomization of urban structure.

When speaking about the regional economic patterns, the results point to the "dividing“ axis bisecting the country diagonally on "upper" and "lower" parts. The upper part represents relatively developed districts, including the most developed part of the country in the west (Bratislava region) followed by central and northern Slovakia. Conversely, the lower part (excluding Kosice metropolis) represents the most underdeveloped regions, located mainly along the Hungarian and Ukrainian borders. Such pattern has been recalled in number of studies (Uramová et al., 2008; Michálek et al., 2014; Mura and Hajduová, 2021).

The above described urban patterns resulted in distinct district subsets as a result of the used AHC method. The AHC method based on searched urban indicators constructed distinct sets grouping similar districts and separating dissimilar ones. The resulting dendrogram highly corresponds with the obtained results.

Finally, the relation between the urban pattern and development level was examined. Formally, the hypothesis about distinct urban patterns, which condition different district levels of development, was tested by statistics - $\kappa$, kappa coefficient of concordance. The district pairs match in both dendrograms was estimated ( $\mathrm{po}=0.278$ ); however, the random probability of concordance was set ( $\mathrm{pe}=\mathbf{0 . 2 1 3}$ ). Hence, the kappa coefficient turned $\kappa=0.0822$, which is indeed a very low value ( 0 - zero concordance, 1 perfect concordance). Finally, based on the findings, we might conclude that we have found only little evidence to support the hypothesis that underlying urban pattern suggests a precondition of the subsequent level of development. Thus, it means that districts with different urban patterns match economic development in a differentiated manner. This main finding might come as surprise. This implies that either centralized or scattered urban structure may lead to more or less successful regional development. Quigley (1998) explains factors that play a significant role when forming clustered and dispersed urban patterns. The first-scale economies are the historical rationale for the existence of cities in the first place. Indeed, without scale economies in production, economic activities would be dispersed to save transportation costs. Without scale economies, there is no role for the city, at all. To the extent that heterogeneity or variety encourages larger-sized urban areas that can take better advantage of scale economies, these basic factors will increase the output of larger cities and the utility of their residents. However, traditional models of the optimal city size (Mills, 1967; Henderson, 1974) clearly establish that we would not be better off collectively living in 'Greatest New York'. Land and housing prices 
increase with city size, and commuting costs do, too. These factors place efficiency limits on the city size. Other models emphasize the importance of unpriced congestion, pollution and externalities in further limiting the size of the efficient city (Quigly, 1998).

Pacione (2009) highlights the key components of an emerging 'new economy' of the inner city. At the intra-metropolitan scale, new industrial clusters centred on innovative, knowledge-based, technologically intensive activities such as computer graphics and imaging, software design and multimedia industries, and technologically 'retooled' industries such as architecture and graphic design cites were cited among them.

Physical structures integrated within the urban morphology may play a vital function in endogenizing the growth effects. Castells (1996) mentions the development of technopoles as a result of the clustering of specific varieties of the usual factors of production: capital, labour, raw material brought together by some kind of institutional entrepreneur and constituted by a particular form of social organisation. Benko (2000) states that technopoles are observed as a positive regional development tool. Predominantly, old industrial regions have sought to create technopoles to change their overall image within the framework of industrial reconversion to attract new economic activities and modernise the local industrial fabric. On the other side, urban locations offer economies of scale, an intense concentration of high-technology based activities and the possible transition between traditional and new technologies. However, he observes them more likely as a spatial concentration of technology transfer and stresses that technopoles might show up as driving forces of polarization of economic activity across geographic space, or worse, a technopole created in a given location by implementing specific policy may end up a merely a 'white elephant'.

Finally, empirical studies have not reached an agreement about the circumstance under which urban polycentricity improves economic performance (Zhang et al., 2017). Meijers and Burger (2010) and Kwon and Seo (2018) found a positive relationship between polycentric spatial structure and economic performance or labour productivity; yet, other authors found contrary evidence. Wang et al. (2018) learned that smaller cities tend to benefit more from regional agglomeration that larger cities do. Also, they found significant synergy effects of intra-city and inter-city polycentricity when measuring capital labour ratio with capital stocks and weak synergy effect was found when measuring capital labour ratio with capital flows.

Thus, we might conclude that underlying urban structure, be it centralized or dispersed, does not automatically make regions advantageous or disadvantaged. Furthermore, it seems that monocentric districts fail to make a substantial difference in economic performance, through agglomeration economies. There should be another complex of factors, not included in the analysis, which play role in economic performance determination. Polese (2009) highlights the historical legacy of a negative cluster of industries as a major development obstacle. Thus the industries (often steel, coal, textile, etc.) which were powerhouses of the regions in the past often turn to its decay. In its influential paper, Gallup et al. (1999) cite that location and climate particularly have large effects on income levels and income growth, through their effects on transport costs, disease burdens, and agricultural productivity, among other channels. However, the geographic location is what matters the most. Africa is especially hindered by its tropical location, by its high prevalence of malaria, by its low proportion of the population near the coast, and by the low population density near the coast. By contrast, Europe, North America, and East Asia, the core regions are favoured on all three counts. A coastal economy, for example, may face a high elasticity of output response with respect to trade taxes, while an inland economy does not. As a result, a revenue-maximizing inland sovereign may choose to impose harsh trade taxes while a coastal sovereign would not.

Even, the decline of rural areas is not predestined. It is by the interactions between rural areas and the external environment that rural communities either grow, decline, or even vanish. In this process, rural communities of different geographical conditions, natural resource endowments and social relationships, and people's values, attitudes, and institutions will make different responses, which would finally lead to different evolution patterns and outcomes (Li et al., 2019).

\section{REFERENCES}

Alonso W. (1970), What are new towns for? Urban Studies. 7(1), 37-55 DOI: https://doi.org/10.1080/00420987020080031

Akkoyunlu S. (2015), The potential of rural-urban linkages for sustainable development and trade. International Journal of Sustainable Development \& World Policy.

DOI:10.18488/journal.26/2015.4.2/26.2.20.40

Anas A., Arnott R., Small A. K. (1998), Urban Spatial Structure. Journal of Economic Literature, 36(3),1426-1464

AUREX spol. (2019), Stratégia územného rozvoja Slovenska. Aktuálne zmeny v oblasti územného rozvoja Slovenskej republiky (Territorial development strategy of Slovakia - Current changes in the field of territorial development of the Slovak Republic). [Book in Slovak]. [online],

URL:https://Aktualne_zmeny_v_oblasti_uzemneho_r ozvoja_SR.pdf. Accessed on 18.6.2021 
Batty M., Besussi E., Chin N. (2003), Traffic, urban growth and suburban sprawl. [online], URL: https://discovery.ucl.ac.uk/id/eprint/216/1/paper70.p df. Accessed on 8.6.2021

Benko G. (2000), Technopoles, high-tech industries and regional development: A critical review. GeoJournal, 51, 157-167

Castells M. (1996), The Rise of the Network Society. Oxford: Blackwell

Clark J., Harrison J., Miguelez E. (2018), Connecting cities, revitalizing regions: the centrality of cities to regional development. Regional Studies. DOI: 10.1080/00343404.2018.1453691

Cottineau C., Finance O., Hatna E., Arcaute E., Batty M. (2019), Defining urban agglomerations to detect urban economies. Environment and Planning B: Urban Analytics and City Science. https://doi.org/10.1177/2399808318755146

Drinka R., Majo J. (2016), Velké vidiecke obce na Slovensku - vybrané charakteristiky plodnosti na začiatku 21. Storočia (Large rural communities in Slovakia - selected fertility characteristics at the beginning of the $21^{\text {st }}$ Century). Geographical Journal, 68, 301-317. URL:

https://www.sav.sk/journals/uploads/o1311510Drinka, \%20Majo.pdf

Faltan L., Pasiak J. (2004), Regionálny rozvoj Slovenska: Východiská a súčasnýstav (Regional Development of Slovakia: Outlines and the current state). Bratislava: SAV. [Book in Slovak]. ISBN 8085544-35-0

Gallup L. J., Sachs D. J., Mellinger D. A. (1999), Geography and Economic Development. International Regional Science Review. DOI: https://doi.org/10.1177/016001799761012334

Galster G., Hanson R., Ratcliffe M. R., Wolman H., Coleman S., Freihage J. (2001), Wrestling Sprawl to the Ground: Defining and Measuring and Elusive Concept. Housing Policy Debate 12(4), 681-717. DOI: https://doi.org/10.1080/10511482.2001.9521426

Geltner M. D., Miller G. N., Clayton J., Eichholtz P. (2014), Commercial Real Estate: Analysis and Investments (2nd ed.). OnCourse Learning. ISBN-13: 978-1-133-10882-5

Havierniková K., Lemańska-Majdzik A., Mura L. (2017), Advantages and Disadvantages of the Participation of SMEs in Tourism Clusters. Journal of Environmental Management and Tourism, 8 (6), 12051215. DOI: https://doi.org/10.14505//jemt.v8.6(22).07 Hendl J. (2012), Přehled Statistických Metod (Statistical Methods Overview). Fourth Edition. Praha. ISBN 978-80-262-0200-4. [Book in Slovak]

Henderson V. J. (1974), "The sizes and Types of Cities". American Economic Review, 64(4), 640-656

Hrdina V. (2010), Zmeny v osídlení/územný rozvoj na Slovensku po roku 1989. [Settlement changes/spatial development of Slovakia after 1989]. Urbanismus 34 a územnírozvoj. [Article in Slovak]. 8(5), 148-156. URL: https://www.uur.cz/images/5-publikacni-cinnost-aknihovna/casopis/2010/2010-05/16_zmeny.pdf

Joint Research Centre (2020), Testing the degree of urbanization at the global level, Slovakia - Country summary, European Commission. [online]. URL: https://ghsl.jrc.ec.europa.eu/CFS.php. Accessed on 18.6.2021

Kourtit K., Nijkamp P., Partridge D. M. (2015), Challenges of the New Urban World. Applied Spatial Analysis and Policy. DOI: 10.1007/s12061-015-9155-1

Krugman P. (1996), Urban Concentration: The Role of Increasing Returns and Transport Costs. International Regional Science Review. DOI: https://doi.org/10.1177/016001769601900202

Krzysztofik R. (2016), Revisiting the question of centripetal and centrifugal forces in urban systems. Geographia Polonica.

DOI: http://dx.doi.org/10.7163/GPol.oo66

Kwon K., Seo M. (2018), Does the Polycentric Urban Region Contribute to Economic Performance? The Case of Korea. Sustainability, 10(11), 4157. DOI: https://doi.org/10.3390/su10114157

Li Y., Westlund H., Liu Y. (2019), Why some rural areas decline while some others not: An overview of rural evolution in the world, Journal of Rural Studies, 68, 135-143. DOI: 10.1016/j.jrurstud.2019.03.003

Limtanakool N., Dijst M., Schwanen T. (2007), A theoretical framework and methodology for characterizing National urban systems on the basis of flows of people: empirical evidence for France and Germany. Urban Studies 44(11), 2123-45. DOI: 10.1080/00420980701518990

Lityński P., Hołuj A. (2021), Macroeconomic Perspective on Urban Sprawl: A Multidimensional Approach in Poland. Land 1O(2), 116. DOI: https://doi.org/10.3390/land10020116

Liu Z., Liu S. (2018), Polycentric Development and the Role of Urban Polycentric Planning in China's Mega cities: An examination of Beijing's Metropolitan area. Sustainability, 10(5), 1588 DOI: https://doi.org/10.339o/su10051588

Madajová M., Michálek A. Podolák P. (2014), Úroveň Regionálnych Disparítna Slovensku a jejzmena v obdobírokov 2001 - 2011. [The level of regional disparities in Slovakia and its change in the period 2001-2011]. Geographica Slovaca, 28. [online]. [Article in Slovak]. URL:https://www.sav.sk/journals/uploads/02051156G eog\%20Slovaca_28.pdf. Accessed on 22.6.2021

Maris M. (2020), Municipal changes in Slovakia. The evidence from spatial data. European Journal of Geography, 11(1), 58-72.

DOI: https://dx.doi.org/10.48088/ejg.m.mar.11.1.58.72 Meijers E. J., Burger M. J. (2010), Spatial structure and productivity in US metropolitan areas. Environment and Planning A. Economy and Space, 42(6), 1383-1402. 
DOI: https://doi.org/10.1068\%2Fa42151

Melo C. P., Graham J. D., Noland B. R. (2009), A meta-analysis of estimates of urban agglomeration economies. Regional Science and Urban Economics, 39, 332-342. DOI:

https://doi.org/10.1016/j.regsciurbeco.2008.12.002 Ministry of Transport and Construction of Slovakia (2019), Slovakia Territorial Development Strategy. [online]. URL: https://www.mindop.sk > vystavba-5 > dokumenty

Mills E. S. (1967), An Aggregative Model of Resource Allocation in Metropolitan Areas. American Economic Review, 57, 197-210

Mura L., Hajduová Z. (2021), Small and medium enterprises in regions - empirical and quantitative approach. Insights into Regional Development, 3 (2), 252-266.

DOI: https://doi.org/10.9770/IRD.2021.3.2(6)

OECD (2018), Rethinking Urban Sprawl: Moving towards Sustainable Cities. OECD Publishing, Paris. DOI: https://doi.org/10.1787/9789264189881-en

Pacione M. (2009), Urban Geography. A Global Perspective. Third ed. Routledge: New York

Polese M. (2009), The Wealth \& Poverty of Regions: Why Cities Matter. The University of Chicago Press

Partridge D. M. (2010), The Dueling Models: NEG vs Amenity Migration in Explaining U.S. Engines of Growth. Papers in Regional Science. DOI:10.1111/j.1435-5957.2010.00315.x

Quigly M. J. (1998), Urban Diversity and Economic Growth. Journal of Economic Perspectives, 12(2), 127- 138

Rosenthal S. S., Strange C. W. (2004), Evidence on the nature and sources of agglomeration economies. Handbook of Regional and Urban Economics. DOI: 10.1016/So169-7218(04)07049-2

Segal D. (1976), Are There Returns to Scale in City size? Review of Economics and Statistics.DOI: https://doi.org/10.2307/1924956

Sloboda D. (2005), Charakter sídelnej štruktúry Slovenska ako predpoklad pre komunálnu reformu (Character of the settlement structure of Slovakia as condition for communal reform), Konzervatívny inštitút M.R.Štefánika [Conservative Institute of M. R. Štefánik]. [Book in Slovak]. URL: https://www.komunal.eu/images/pdf/Sloboda_komref orma.pdf

Statistical Office of the Slovak Republic (2021), Size Groups of Municipalities. SO SR, 2021. Statistical database

http://datacube.statistics.sk/\#!/view/en/VBD_DEM/o m7022rr/v_om7022rr_0o_oo_oo_en

Sveikauskas A. L. (1975), The Productivity of Cities. Quarterly Journal of Economics. https://doi.org/10.2307/1885259

Sveda M., Suska P. (2019), Suburbanizácia: Ako sa mení zázemie Bratislavy? (Suburbanization: How
Bratislava's hinterland changes?). Geografický ústav SAV. [Book in Slovak]. ISBN 978-80-89548-o8-8

Sveda M. (2014), Bytová výstavba v zázemí vel'kých slovenských miest $\mathrm{v}$ kontexte suburbanizácie a regionálnych disparít. (Dwelling construction in the hinterland of large Slovak cities in the context of suburbanisation and regional disparities). Geographia Slovaca, 28, 173-197. [online], URL: https://www.sav.sk/journals/uploads/02051156Geog\% 20Slovaca_28.pdf. Accessed on 18.6.2021

Tacoli C. (2003), The links between urban and rural development. Environment \& Urbanization. DOI: https://doi.org/10.1177/095624780301500111

Tacoli C., Satterthwaite D. (2003), The Urban Part of Rural Development: The Role of Small and Intermediate Urban Centres in Rural and Regional Development and Poverty Reduction. Working Paper. International Institute for Environment and Development. URL: https://pubs.iied.org/922iied. Accessed on 12.6.2021

Tacoli C. (1998), Rural-urban interactions: a guide to the literature. Environment and Urbanization. DOI: https://doi.org/10.1177/095624789801000105

Tichý D. (2005), Združovanie obcí ako predpoklad rýchlejšieho rozvoja samospráv a regionov. [Creating of Associations of Communities as a Precondition of Faster Development of Municipalities and Regions]. Journal of Economics, 53(4), 364-382

Tsai Y. H. (2005), Quantifying Urban Form: Compactness versus 'Sprawl'. Urban Studies 42, 141161. DOI: $10.1080 / 0042098042000309748$

Uramová M., Kožiak R. (2008), Regional Disparities in Slovakia from the Aspect of Average Nominal Wage. Ekonomie a Management (E+M), 11(2), 6-18. URL:

https://ekonomiemanagement.cz/download/1331826667_e672/o1_urm aova.pdf. Accessed on 22.6.2021

Veneri P. (2015), Urban Spatial Structure in OECD Cities: Is Urban Population Decentralising or Clustering? OECD Regional Development Working Papers 2015/01.

DOI: https://dx.doi.org/10.1787/5js3d834r3q7-en

Wang M., Derruder B., Liu X. (2019), Polycentric urban development and economic productivity in China: A multiscalar analysis, 51(8). DOI: https://doi.org/10.1177/0308518X19866836

Zhang T., Bindong S., Li W. (2017), The economic performance of urban structure: From the perspectives of Polycentricity and Monocentricity. Cities, 68, 18-24. DOI: http://dx.doi.org/10.1016/j.cities.2017.05.002

Zubriczký G. (2014), Regionálne členenie Slovenska z pohl'adu jeho rozvoja. [Regional division of Slovakia from the point of view of the development]. In: Lauko, V. eds. Regionálne dimenzie Slovenska. [Regional dimensions of Slovakia], 199-215. [Book in Slovak].

Zarska E., Balazova E., Kozovsky D. (2007), Komunálna ekonomika a politika. (Communal economics and policy). Ekonom [Book in Slovak]. 